\title{
СЛОВЕНСКА САМОСВЕСТ МОДЕРНЕ СРПСКЕ ПОЕЗИЈЕ ${ }^{* *}$
}

\begin{abstract}
Хердерове идеје из епохе романтизма о еманципацији и потенцијалима словенских култура задобијају нов контекст и смисао у раздобљу авангардног преокрета у уметности. Најпре се фокусирамо на рефлексе руске револуционарне епохе у програмским поставкама Станислава Винавера, те на различна испољавања словенског неомитологизма и словенске самосвести у српској авангардној поезији. Међуратни отклон од европоцентричне позиције (нпр. Мицићев зенитизам) на трагу је руске критичке мисли о Европи, културних идеја Достојевског, Шпенглера и тада актуелне теорије евроазијства (Николај Трубецкој). Прати се преиначење идеје о самосвојној југословенској књижевности и култури ка идеји о новој балканској култури (Растко Петровић, Милош Црњански, Раде Драинац). Одјеке оваквих тежњи сагледавамо и на изабраним примерима након Другог светског рата (Васко Попа, Миодраг Павловић, Десанка Максимовић, Стеван Раичковић и Љубомир Симовић).

Кључне речи: савремена српска поезија, словенски неомитологизам, југословенски месијанизам, културна самосвест, културни симболи.
\end{abstract}

Колико може бити продуктивно истраживање словенске самосвести модерне српске поезије ако знамо да је далека 1848. година била „врхунац словенског осећања код Срба”, а да „после тога то осећање слаби, а искључиво српско национално осећање јача", како наводи Јован Скерлић у Историји нове српске књижевности: „Место идеала 'Славјанског Царства' долази идеал 'Душановог Царства', и из панславизма четрдесетих година излази ужи српски национализам” (2006: 198). Српска народна самосвест на таласу романтизма на дужи рок односи превагу, да би тек на међи векова била озбиљно стављена на испит, у име отварања према ширим културним перспективама, наравно - с претежним погледом на западне стране.

Поткрај Првог светског рата и након почетка Руске револуције Томаш Масарик пише расправу Нова Европа. Словенско становиште (1918), где разматра поли-

\footnotetext{
"hamovicdragan@gmail.com

*** Текст је настао као резултат рада на пројекту „Смена поетичких парадигми у српској књижевности 20. века: национални и европски контекст” (178016), који финансира Министарство просвете, науке и технолошког развоја Републике Србије.
} 
тичке и културне димензије насловне теме. Видећи изворе панславизма у немачкој философији историје и Хердеровом концепту народа̂ „као природних органа човечанства”, тј. у националном принципу, Масарик повлачи значајну разлику између пангерманске идеје о надређености другима и панславизма који се ,задовољавао литерарном и културном узајамношћу” (2016: 159). Опет, с почетка двадесетих, Николај Трубецкој, доспео у емиграцију, „словенски карактер” и „словенску психу” одлучно оглашава за митове:

„Сваки словенски народ има свој особен психички тип [...] 'Словенска култура' је такође мит, јер сваки словенски народ изграђује своју културу самостално, и културни утицаји једни на друге нису јачи од утицаја Немаца, Италијана, Турака и Грка на те исте Словене” (2004: 172).

С друге стране, песници на откривене митотворне потенцијале спремно реагују. Управо су првих деценија 20. века руска и српска књижевност у знаку „словенског неомитологизма" (в. Петковић 2010: 13). О словенској култури се још увек говори као о јединственом ентитету, свакако и под упливом руске мисли, читав претходни век забављене противуречним односом Русије према култури Европе. Бритка разлучења у оквиру тадашњих идејних поларизација даје и млади Николај Велимировић у тексту „Ниче и Достојевски” (1912), у часу када и српску средину дотиче дах ничеанства. Наспрам натчовека уводи се појам свечовека, потекао из мисли Достојевског: „Засад само Словен је у стању бити свечовек, јер Словен познаје два света, свет западно-европски и свет словенски; човек са Запада познаје само Запад" (1996: 342). Словенско становиште бива оснажено у српској средини након страшног судара с пангерманским милитаризмом и стварања Краљевине Срба, Хрвата и Словенаца.

Томе занимању и личним подстицајима Исидоре Секулић дугујемо настанак серије чланака Василија Зењковског, накратко Београђанина, у часопису Нова Европа (1922), ${ }^{1}$ сабраних крајем исте године у књизи Руски мислиоци о Европи. У предговору, Секулићева наглашава епохална колебања, декаденцу Запада: „Руска основна мисао, мисао о Богу, нема декаденце. Та мисао обухвата нас данас све” (нав. према Зењковски 2012: 6-7). Зењковски слично интонира свој увод, алудирајући на актуелну Шпенглерову историософску синтезу: „Није само Немачка она која говори и пише о 'пропасти Запада'. Свуда, свуда царује осећање узнемирења, прети духовна пропаст, доминантна постаје свест о унутрашњем бескућништву" (2012: 11). У таквој поратној атмосфери, криза савремене културе, дотад неупитно европоцентричне, изискује разрешење у ослонцу на словенске потенцијале, или, према речима Зењковског:

„Од Гогоља до Скрјабина, од Скороводе до Фјодорова, руски трагаоци виде у уметности творећу и преображавајућу силу, и када је Достојевски написао да ће 'лепота спасити свет', он је изразио једно од најдубљих веровања руских мислилаца, веровање да уметност крије у себи снагу преображавања живота" (2012: 13).

Словенски, тачније руски месијанизам, од прошловековне словенофилске мисли кристалисан као пројекција глобалног излаза, задобија изопачени лик у октобарским и потоњим револуционарним кретањима. Авангарда је, уосталом, проје-

\footnotetext{
${ }^{1}$ Више о томе у раду Видосаве Голубовић (1910: стр. 239-240).
} 
кат уметничког колико и друштвеног преврата, који оличавају и кубо-футуристи и бољшевици. У својој програмској књизи Громобран свемира Станислав Винавер се пита: „Хоћемо ли завршити наше растење, увирањем у неку Русију” (1921: 49) те поставља Скрјабина насупрот Вагнера и „немачке материјалистичке културе”. Помиње „филозофско-старословенску архаично-декадентску апокалиптичност” Скрјабинове музике и позива се на оцену Вјачеслава Иванова: „Спој, синтеза Скрјабинова: преко свих појединачних пропасти иде величанствена поезија рушења” (Винавер 1921: 69). „Јесам ли добро разумео Иванова”, пита се опет Винавер при почетку текста о руском композитору. Иванов је, да подсетимо, истицао да Скрјабин говори „хорским гласовима саборног мноштва које је подизао из дубина”, из страшне песме „древног рођеног хаоса” (2001: 237). А речи саборност, рођени хаос и стихија кључни су појмови којима је оперисало руско самопознање, а Скрјабинова музика виђена је као израз тога познања.

У књизи Руске поворке (1924) Винавер често изједначава револуционарну и руску народну стихију, не без горке ироније сведока тектонског друштвеног потpeca:

„Ми рушимо без мржње, јер кад бисмо рушили с мржњом, она би се, понеки пут, преобразила у љубав, и ми не бисмо рушили. [...] У рушењу је пијанство, коме ми после тражимо социјалистичко или царистичко оправдање. Ми смо Скити који рушимо" (2015: 55).

Подсетимо на то да је у прочељу трећег броја авангардистичког часописа $3 e-$ нuт (април 1921) отиснута, у оригиналу, песма „Скити” Александра Блока. Мајски број Мицићевог часописа доноси песму „Једрила” Растка Петровића, послату из Париза, у којој читамо и следеће самоодређење лирског Ја: „Прадедови наши Славени, крволочни ал путници [...] Син сам Словена дивљих некада, ал сада путник.” На изучавања о пореклу Словена, оптерећена тамним местима и предрасудама, Растко се осврће још у чланку „Једна теорија о пореклу Словена”, где јетко примећује да нам намећу „своју генијалност, аљкавост и пијанство” (1920: 2). Упућен у токове научне реконструкције словенских почетака, иронијским штитом се опире дејству западних, романо-германских стереотипа, док ће, као авангардист, који лествицу вредности наглавце изокреће, негативне ознаке своје расе примати у афирмативном тону, баш као у песми „Пустолов у кавезу”: „док су по теби барбарства моја словенска / и њини перунски врти, / својом косом као венцем ме узвиси”. Враћа се почецима, рођењу и првим доживљајима своје телесности, иза међе културе, у детињство и дивљаштво оличено у словенским прецима, поистовећује с њиховим лутањем и примитивним одликама као залогом насушног витализма. Словенски пантеон, уведен у поезију и, нарочито, прозу Растка Петровића послужује као материјал за бурлескна поигравања.

С друге стране, Петровић у есејима у којима се посвећено бави разним аспектима словенског наслеђа брани ону представу о прапрецима коју беше обликовао словенофил Хомјаков, ,мирољубивих, земљорадничких племена који су и пре примања хришћанства били носиоци древног иранизма” (вид. Суботић 2001: 140), а иранизам „почива на поштовању слободног стваралачког духа, на представи о Богу као творцу и хришћанство представља њен највиши и најчистији облик” (Исто: 137). Словенско племе на Балкану, читамо у једном Растковом есеју, „носи реноме 
изврсних бораца у тренутку рата и часних сељана за време мира", а живот им је ,још увек близу примитивног, буколичан и георгичан” (1975: 298). За таквим истим менталитетским портретом предака трага и Црњански, кроз уводни део биографије Свети Сава (1934):

„Много више него у подацима о другим варварским народима, у та времена, речито нам говори из тих спомена необична душа Словена, пуна прича и гатања, што је сачувала у себи присну везу са светлошћу небеских пожара, тамом шума и животом бившим, у травама и водама, у спокојству земљорадничком, најбољој страни, и сад још, у бићу нашег народа" (Црњански 1999б: 11).

И унутар Хиперборејаща аутор иде за тим словенским трагом, назирући заједничке претке под разним именима нађеним код античких писаца, у описима скитског безбрижног живота у земуницама, у пијуцкању медовине - а непромењен животни образац, у коментарима Итаке, распознаје по повратку из рата и код завичајних Иланчана, у Банату.

Добро је познат Црњансков програмски текст „За слободни стих” (1922), један од кључних за поимање првог таласа српске авангарде. Насловна тема, оправдање напуштања дотадашњих погодби стиха, као да је одвратила пажњу са једне од важних програматских реченица у првом делу текста, у којој се „словенско становиште” помиње као нешто битно и саморазумљиво:

„Јер и без неке националне теорије: 'transformation des nations directrices', сад, после уједињења, однос наше уметности према европскима постаје други. Најновија руска музика, чешки футуризам и Мештровић, први су знаци тих нових, словенских појава” (Црњански 1999а: 24).

Рез који је настао Великим ратом био је сувише велик да би „однос наше уметности према европскима” остао исти као пре рата. Предратна уметност је „музеј европских копија", каже Црњански и заступа потребу напуштања француске версификације и заснивања оригинално наше, „сазидане на традицијама народним” и „расном изразу”. Словенство и карамазовштина чине лајтмотив Црњансковог повољног критичког осврта на поезију Иве Андрића (в. Исто: 280). Као критичар, Црњански показује резерву према старословенском слоју Откровеља Растка Петровића, али оданде ипак чује и „крик наше расе” после милиона бесмислених смрти (320). У путопису Љубав у Тоскани (1930) исписује: „Дошао сам, јер осетих једног дана јасно своју судбину Словенства, безмерну будућност што ме је слала у Тоскану, у име Руса и Пољака, Бугара и Словака” (Црњански 1983: 111). Наспрам толиких „бесмислених смрти” идеју о рађању види као „очишћење од сељачких бесова, спасење од умора словенског”. Породиља постаје тамна и слатка нада, „ради оних што помреше по петроградским улицама, по нашим бедним паланкама и у туђини, надајући се свему од Словенства" (Исто: 152). На видику Црњанског свуда је Словенство, које је, у доживљају путописца, „дрхтало као звезда зорњача” (Исто: 221).

Пошто је у песмама Лирике Итаке десакрализовао родитељство и чин рађања, саму основу људске културе, сада га, међу сијенским Богородицама што „личе на кијевске”, изнова сакрализује. Већ је писано о томе да се лирски субјект Црњанскове програмске „Моје песме” удваја у две предачке историјске фигуре, сељака и граничара (сережана), чији је траг уочљив и у низу других песама. Двојничка фигура оружаног најамника без дома и отаџбине, еквивалент ратном искуству самог песника колико и његових предака на војној граници између Запада и Турака, обликује 
се као симбол невољног словенског искуства. ${ }^{2}$ Словенским траговима проткане су смисаоно маркантне песме Лирике Итаке. У песми „Химна” рецимо: „Ни мајке ни дома не имадосмо. / Селисмо нашу крв”, или у песми „Народни вез”: „Цео свет је за мене вез / пун шара моје крви". Нису, значи, код Црњанског, као код Растка, путника и скитача, преци оличени једино у дивљим Скитима, него у доцнијем историјском лику, у припадницима словенских пукова на граници царстава и млетачких „скјавонских најамника", али се обојица с фигурама робусних предака поистовећују, на њиховим постојаним одликама заснивају лични идентитет. Преци су унутар нас, нису прошлост.

Матица откривене, препознате „расне” самосвести у случају оба авангардна гласа има деромантизовано, али обновљено словенско извориште. То је знак интуитивне нађености „у тражењу себе”, да употребимо насловну синтагму једног од Настасијевићевих програмских есеја:

\footnotetext{
„Намеће се у овом погледу поређење с Русима. Код њих је расцеп тражења себе на дому и тражења себе у свету дубљи и трагичнији од нас. Коренитије се у руској земљи остајало и коренитије из ње бежало, па се из оштрине сукоба родила мисао, дубоко се поставио проблем" (1991: 110-111).
}

Српски преводилац Шпенглера, Владимир Вујић, у чланку „Општечовечанско и локално" (1932), користи термине преузете из Пропасти Запада и сведочи што и Настасијевић. Велики је проблем „пред јужнословенском књижевношћу: стварање свога или уобличавање кроз туђе, оригинално стварање или лажно формирање, напор и развој самосталном казивању живота или псеудоморфоза” (Вујић 2013: 129). ${ }^{3}$

Родна мисао, дубока и жртвена, коју помиње и својски решава Настасијевић, насупрот површности властитог искорењивања кроз примање туђих модела и „привида културе”, била је упориште и Црњанском и Петровићу, неизбежно обележена базичним словенским знаком. Носиоци српске авангардне поезије били су учесници обухватнијег културног пројекта након Великог рата и народног ослобођења. Владимир Велмар-Јанковић описује контуре тога генерацијског подухвата, подложеног мишљу о свечовечанском словенском месијанизму. „Верујемо да за стварање наше слободне народне културе постоји у душама нашим запретан основ поуздања у историјску мисију нашег народа, у његово нарочито посланство које му је наменила судбина” - пише Велмар-Јанковић у тексту „За прву оријентацију” (1928): „Корен те вере налазимо у инстинктивном и реалном убеђењу да је словенским народима додељена улога да за вољу једне боље и достојније човечности помире у себи и нађу вишу синтезу два света, Истока и Запада” (2006: 35). Растко Петровић, коме је тешко приписати конзервативне погледе, у есеју „Између Истока и Запада (идејни хашишизам у књижевности)" (1930) такође пројектује мисију помирења Истока са вредностима Запада и стварања (,генијем расе”) општечовечанске културе (1975: 193).

Месијанистичке примисли, у својој југословенској редакцији, очито су обухватале и средишњи српски културни ток, као и авангардну бунтовну периферију

\footnotetext{
${ }^{2}$ Више о томе у: Хамовић 2016: 89-108.

${ }^{3}$ Више о утицају Шпенглера на међуратну књижевну мисао у: Димитријевић 2016: 196-212.
} 
након Великог рата. У манифесту „Дело зенитизма” (Зенит, 8), Љубомир Мицић декларише медијалну позицију Балкана у повесним сударима Истока и Запада, идеју коју ће доцније варирати: „Ми можемо бити само пионири и деоници стварања једне нове свечовечје културе коју собом носи ИСТОЧНИК Човек с Урала, Кавказа и Балкана - рођен у колевци која се зове РУСИЈА. Балкан је мост између Истока и Запада" (1921: 2). Подстицај за пренос фокуса са словенског на балканско подручје могао се наћи у написима Трубецког: „Јужни Словени ушли су у сферу утицаја Византије и заједно с другим племенима Балканског полуострва учествовали у стварању особене 'балканске културе', хеленистичке у својим врховима, која се у подножјима не да подробније етнолошки одредити” (90). У „Зенит манифесту 1922” (Зенит, 11) Мицић додатно распирује своју барбарогенијску пројекцију: „Ми смо Балканци - Источници / Стварамо / балканску уметност / да / балканску културу / Хоћемо БАЛКАНИЗАЦИЈУ ЕВРОПЕ” (Мицић 1922: 1), да би, у распри са загребачком средином у којој је деловао (Зенит, 24), кориговао првобитно виђење „балканске мисије”. Разликује „српски конструктивни балканизам” и „деструктивни хрватски европеизам”: „Балканизација Европе, наш је позив и заповед. Балканизам је праснага древног огњишта прве европске културе, те као синтеза дивљега славенизма и зрелих плодова класичног хеленизма" (1923: 2).

Сличне декларације истовремено шаље и Раде Драинац у „Програму хипнизма” (Хипнос, 1, 1922): „Време је да се Балкан запали духовно. Доста нас је понизно за петама лизао католицизам, папски Рим и галска ватра Париза. А тако смо близу сунцу Истока” (Драинац 1999б: 9), или, у наредном броју Хипноса (1923): „Ми не смемо да живимо по рецепту странаца. Време је, да нас, Балканце, пренесу преко границе, јер наша дивља душа има све особине помућене шекспировске генијалности” (Исто: 10). У листу Правда, након више година, објављује манифест „За балканску културу” (1931), с познатим звучним ставовима: „Отвореном борбом противу западне културе ја сам се бацио свом снагом на изграђивању једне новије и човечанскије културе: балканске културе [...] Боримо се противу западне културе, противу индустријске и економске предоминације" (Драинац 1999б: 28, 30).

Драинац уводи у насловну песму своје збирке Бандит или песник (1928) и назив актуелног покрета у окриљу руске заграничне мисли: „Поздравило ме пролеће балканско са својим необузданим цветањем. [...] Још једна неурастенична зора натапа моје лице / У болну гримасу еуразијских егзалтација." Поборник евроазијства, Трубецки, по аналогији с појмом ,језичког савеза" генетски различитих језика у блиском додиру, наспрам идеје о заједничкој словенској култури, даје теоријску легитимацију новој балканској култури, истицањем значаја ,ареалних и географских веза међу народима разнородног порекла" (Станишић, у: Трубецки 2004: 201).

\footnotetext{
${ }^{4}$ Први је Новица Петковић прочитао многима нејасну синтагму еуразијске егзалтације оцртавајући културни наратив којим се овде бавимо, дуго потиснут из књижевноисторијског хоризонта, упућујући на евроазијску теорију „коју су двадесетих година, управо у Београду као и у Софији и Паризу, заступали руски научници у емиграцији”: „И ма шта ми данас мислили о тој теорији, она је морала бити блиска Драинчевој замисли балканске културе, макар тиме што је одбијала, шпенглеровски речено, европску културу на заласку”, објашњава Петковић и поентира: „И као што се истицало да руска не сме бити њена копија ни провинција, него улази у засебан источноевропски и азијски културни круг, тако исто и српска улази у засебан балкански културни круг” (2007: 87).
} 
Ознака Драинчеве поетике као „деконцентрисане” вреди и за евроазијска уверења у његовој поезији. Наиме, када пролазимо кроз Драинчеве песме у којима се, у дисперзивном асоцијативном току, појављују искази о словенству и балканству, чини се да песник неретко упада у полемику с властитим програмским поставкама, да их деконцентрише и деструише, клонећи се и властитог догматизма и клишеа о словенској осећајности: „Мрзим словенску тугу као на анзис картама / Душу бих хтео да ослободим од винограда и звезда”, налазимо у песми „Воз одлази”, док у песми „Варљиве звезде” помиње „словенску мрачну грандиозност што спава у дну вена”, а „излишну словенску меланхолију” у песми „Банкет”. Опет, у песми „Улис II” читамо и ово: „Пљујем на ту фамозну словенску душу, / Натопљену у сирће мистицизма!” У песми „Тестамент блудног сина” се поистовећује с ликом Руђина од Ивана Тургењева: „Потребно је у будућности да ме неко спасе баналности, / Данас кад пијем и мењам возове, / Сав предан огромној словенској фаталности".

Тек се јаснија потврда програма „балканске културе” сагледава у песми „Нова земља":

„Крик за земљом није ли побуна крви у нашем варварском телу? / Волим тај јецај за њом, и певам све трагедије балканских поља и њива [...] А величајући мостове на Дунаву, Сави, Марици и Вардару / Ја славим напор тврђи од гранита [...] О крвави крик за земљом, оштрији од свакога ножа, / За Земљом и Слободом! / Волим тај јецај за њом, и певам све трагедије балканских поља и њива, Ја, први песник балкански.”

Невеселу лабудову песму свога балканизма, с алузијама на нове заплете у германско-словенским односима, исписује Драинац у „Поеми” из заоставштине, датованој у 1941. годину (в. Тешић, у: Драинац 1999а: 325-332). У „Поеми” се јавља „занесен балкански хајдук” те сагледава новонасталу ратну ситуацију:

„Почео је да влада чудак из минхенске крчме и највећи шарлатан / што га је свет родио! [...] Србији славној у груди зарио мач тефтонски нитков. // Побише нас браћа! И неће заборавити свет / Крв Срба што у земљу потања.”

Словенско откровење у водећим делима српске авангардне и поставангардне поезије није ипак поглавито културно-идеолошко, него је више питање преиспитивања и одређивања према унутрашњем наслеђу, навирућем из дубина пробуђене и стратешки побуђиване свести. Према јунговцу Нојману, „модерна структура свести темељи се на интеграцији, и свако Ја датог времена мора у свом развоју прерадити битне делове културне прошлости који му се васпитањем преносе као вредносни канон његове културе" (1994: 9). Авангарда, отуда, није значила само одбијање затечене традиције и „величанствену поезију рушења”, него откриће и рехабилитацију садржаја потиснутих или неуведених у простор културног самоописа, нарочито садржаја почетних, у личном и колективном искуству. Битни су делови културне прошлости у несвесном посложени и авангарда настоји да их изведе на површину свести и текста. Прошлост није протекла и нестала, остала је унутар нас, до самих почетака културе. Над овим је темама наднет интуитивни тумач попут Растка у есејима далекосежним за претемељење српске и словенске самосвести, као што су „Младићство народног генија” и „Народна реч и гениј хришћанства”, али и у путописима с локација најраније словенске културне географије („чудно подсећање на наш најосећајнији живот што протицаше кроз нас”). Као што каже у песми „Пусто- 
лов у кавезу”, почетној у збирци Откровење: „Има такве неке моћи у мени да само једно могу; / све је утопљено: бескрај, пустоловина, манастири, / мој живот ми сија као звезда издалека."

После Другог светског рата и политичке епитимије над опусом невољног емигранта Растка Петровића, важан тренутак за његов велики повратак у видокруг поставангардног модернизма чини есеј Зорана Мишића (1961). Истицао је тада Мишић да је Растко

„био на најбољем путу да оствари синтезу коју нико није био остварио, да измири крајности које се још ни данас не могу измирити: да приближи Исток и Запад у нама и повеже нашу прошлост са садашњицом; да збратими своје пустоловне словенске претке, бахате и чемерне, са модерним европским пустоловима утанчаних и неуротичних чувстава" (1963: 165).

Ипак, синтеза коју је Петровић започео, уз друге међуратне песнике, већ је била прилично замакла у остварењу, у поезији коју је Мишић свесрдно подржавао. Реч је, пре других, о Васку Попи.

Парадокс уметности речи учинио је да визију екстатичног, многореког и спонтаног откриваоца невиђених новина и неистражених дубина оствари церебрални и екпресивно редуковани песник, идући трагом фолклорних основа и активираних архетипских симбола. Међу тим симболима су националне историјске фигуре, као што су Свети Сава, Венцоносац с Косова поља и његови бојовници, Црни Ђорђе - али то су фигуре обремењене знацима још дубље дубине. Ту је тотемски Вук, чији двоструки, и хтонски и соларни, глас допире из недовршене поеме Растка Петровића и Попине Вучје соли (1975) и коме се ауторски глас одазива. Словенска света липа добија код Попе централно место, пре свега у космологији спева Споредно небо (1968). Некадашња липа насред села у Попиној топографији постаје „Липа насред срца", бива поунутрашњена као крунски знамен наслеђа, преношеног као надлични садржај свести. „Васко Попа је у Споредно небо уградио једну знатну симболошку ерудицију”, читамо код Ивана В. Лалића који опажа „карактеристично присуство неких слика и симбола из словенског фолклорног мита" (1997: 113) и описује особену Попину стратегију употребе древних симбола. Према Лалићевом увиду, он „гради слике које у склопу његове комуникације дејствују самостално, примарно као поезија, али су у исто време укотвљене у древни симбол”, па изграђена слика „ненаметљиво продире у дубину онога што зовемо колективним сећањем, до симбола, до центра из којег је слика еманирана” (113). Тако је са симболом липе, око којег се смисаоно окупљају криптични лирски сижеи.

На врху липе насред срца „певала млада истина у мраку”, читамо иницијалну слику седмоделног циклуса протканог старословенским знацима, да би се у епилошкој и насловној песми циклуса липа појавила као топос који води до „последње дубине”, „дубље од рођеног живота”. „Млада истина” и „последња дубина” ознаке су наше митске основности - зависно од тога да ли гледамо од почела или према почелу - а словенска липа је дата као читак знак што веже нашу појединачност и колективне почетке, а њих безочно ништимо. Јер табуисану липу сечемо те стога хладнимо у себи, говори завршна песма циклуса „Липа насред срца”. У песмама Усправне земље (1972) симболичко-асоцијативно зрачење липе бива још очевидније. У песми „Врачар поље” лик старца пастира (тј. Свети Сава онамо постхумно 
спаљен) носи „живо вуче око врата” и свира „у липов лист”, док ауторски глас откида липов лист и свирку продужава. У циклусу „Поклоњења хромом вуку” ауторски глас моли словенско божанство да га огњем из чељусти надахне: „да пропевам у твоје име / Праматерњим липовим језиком". Има ли изричитијег програмског опредељења за словенски континуитет, као најдубљу подлогу наше песме и културе?

Доследном стратегијом редукције сликовног мноштва на архетипске симболе, базично словенско наслеђе, митолошки пантеон, Попа највећма своди на два симбола. Тиме је, нема сумње, Попа доспео до циља који је његов заговорник Зоран Мишић прокламовао у есеју „Језик и поезија”, дошао је „до песничког језика националног и универзалног у исти мах, који ће моћи да изрази сензибилност савременог човека и дух наше епохе, остајући при том на своме сопственом тлу, у присном дотицају са живим снагама земље” (1963: 73). Словенски симболи постају лозинке најдубље самосвести песника којом прожима своје модерне лирске светове.

У важном часу ауторског кретања и послератне књижевне еволуције, Миодраг Павловић објављује књигу Велика скитија (1969). Песник развијене историјске свести не посеже овде за словенском митологијом, него за повесном тачком у којој Словени улазе у хришћанску васељену и за чином уласка у обзор писане културе. „И наша ће се голотиња у речи оденути / ко бреза с пролећа у лишће”, налазимо у песми „Словени под Парнасом”, речено гласом незнаног сведока, а у „Епитафу словенског прапесника” чујемо непокорни глас „Ја остајем где сам / у земљи језика мог”. У песми „Солунска браћа” (Нова скитија, 1970), са имперсоналне позиције, Павловић описује мисију Ћирила и Методија с дистанцом ерудитног искуства и без настојања да се приближи предачкој стајној тачки. Павловић у есеју о Растку Петровићу бележи да песниково „одустајање од космополитске вокације, откривање егзотизма у сопственом културном наслеђу, као да је била део оног покрета којим је европска култура [...] бежала од саме себе, ка далеким изворима освежења" (1974: 238). За Павловића, стари словенски свет био је најближи од егзотизама у који ће се рекреативно загледати. Као песник културе, он у прапрецима види „словенско тесто” за које Солунска браћа носе словесну со и квасац и „сеју знаке за сањива племена / и небом отварају изворе млека”. Сложену тему културног обрата, увођења у хришћански Логос и транзиционих тегоба Павловић уткива у песме Велике скитије и Нове скитије, које се крећу уздуж историјске осе, али с почетном свести да ,у песми / а не у рушењу треба провести ноћ”, дакле у смислотворењу, а не у разарању. Сам медијум песме повезује последње са првим у језику и памћењу, па је тематизација почетака историјске меморије, христијанизације и алфабетизације Словена, била упоришна тачка Велике скитије. „Неко је на небу заверу ково / и кидао перунике с ливаде / као што смрт отима војнике. / једно поподне видесмо свог бога / како силази да се купа с нама”, налазимо у песми „Перунов одлазак”.

Антрополошка испитивања одвешће Павловића ка запретаним местима древне усмене лирике и обреда, где налази архајске словенске, сплетене с другим културним слојевима. Међуратно оптирање за сложај балканске културе, код Павловића, чији умни поглед силази низ културну дијахронију, долази до онога што је Мицић звао „праснагом древног огњишта прве европске културе”, до старобалканских извора. Балканизам Павловићев управо се испољава у сапостојању многих знакова културне прошлости, с којима се суочавамо и које ишчитавамо, а од којих је словен- 
ски удео тек један од горњих садржаја, сагласно речима с краја песме „Балкански путопис”: „Све што си видео на Балкану / беху само привид-лађе / на мркој пучини прапочетка”, или пак у спеву Дивно чудо (1982): „Овде око Ртња / обичаји древни / куљају као дивље цвеће / док се са римског града / скидају наслаге хумуса.”

Под утицајем Павловићеве песничке и есејистичке праксе и Љубомир Симовић промишљено зарања низ описану вертикалу, спушта сонду у слојеве тла, посежући и за Чајкановићевом реконструкцијом старе српске религије. Симовић, чији поетски опус почиње збирком Словенске елегије (1958) - и прожет је лирским призивом древности свога народа и алузијама на његове историјске удесе - у зрелој ће фази у завичајну топографију западне Србије уткивати митолошке и псеудомитолошке слике, али и чудесне искораке из сурове реалности у хришћанске епифаније. Гости из облака, као Перун из Павловићеве песме, силазе доле и „божанско за овчарско мењају име и презиме” („Преображење”, Источнице, 1983), а исто тако ликови овдашњих људи и жена узрастају до митских димензија. Женски ликови попут Копилуше и Живане са Субјела, рецимо, пројављују несагледиве демонолошке капацитете. У сликама из Симовићевог митизованог завичаја мире се и тесно коегзистирају овострана и онострана реалност, баш према лику старих српских и балканских веровања и тиме се повраћа нарушена равнотежа животног поретка. Дотле, исти песник, у циклусу „Руске вечере” (Горњи град, 1990), у непосредном суочењу са пределима руске зиме, као удубљени посматрач осликава тамошње духовне пејзаже. Тек у песми „Пахомије” лик српског светогорског монаха што је оставио трага у позној средњовековној култури Русије посредно упућује на давне и подубоке споне. Али је нарочито говорљива „Руска питалица” с питањем „Где је Русија”, прекорно упућеним некоме што је изгледа обећавао „мисирске житнице”, „корпе, каце и трпезе", неописиве висине и даљине, а оставио руски колектив у беди и пометњи, разгоревши чак и град у облаку. Налик библијском Новом Јерусалиму, град у пепелу пре чини слику здања револуционарног пројекта, у име којег се недосегнути земни добитак обећавао, при оној „величанственој поезији рушења”.

Сводећи овај сажет и селективан поглед на манифестације словенске самосвести у модерној српској поезији, сагледаћемо још два истакнута примера из реда тзв. чистих лиричара или неоромантичара, Десанку Максимовић и Стевана Раичковића. „Свет је оно што видим”, писао је програмски Раичковић. Он, рецимо, у сонету „Калемегдан”, налазећи се пред сликом изразито историчног топоса београдске тврђаве, одиста, опис гради без и једне културне асоцијације. Историјску свест своје лирике Десанка црпи из предањског искуства својих ближњих сеоских ликова, који су саставни део завичајног пејзажа. Тако, у песми „Балкански ратови” (Заробљеник сновa, 1960), обична слика уз вино заселих бранковинских сељака, ратника из Балканских ратова, преображава се у заветну икону Кнежеве вечере. У истој збирци, иста песникиња што је, између два рата, преузимала и гласове старих гоњених богумилских јеретика, солидарност показује према „обореном богу”, словенском Перуну, с којим се, као дете, дозивала кроз грмљавину, али благоразумевање преноси и на распетог бога што је Перуна оборио, у сну разговарајући „с онима који трпе”. Не искључујемо у оваквом бранилачком ставу и дискретни рефлекс на идеолошку опресију титоистичког доба. У сонетима збирке Сајам речи (1987), у призваном словенском пантеону „старих богова” Десанка налази могућност ближег, рођачког општења, јер су и људи 
и пагански богови упоредиви у својој несавршености: „Ја још у срцу чувам црквицу стару, / они сви у њезином олтару - / мада и они грешни, мени су свети.” Перун је, у овој лирској пројекцији, домаћин међу домаћим боговима, по аналогији с породичном задругом коју смо имали („Породица богова”). Словенски богови су, заправо, посвећени словенски и српски претходници, чиме песникиња прећутно упућује на начело посмртне дивинизације предака из српског култа мртвих.

С друге стране, у књизи Летопис Перунових потомака (1976), Десанка се упушта у једну добронамерну, али „политичку” интервенцију. Вероватно као песнички одговор на набујалу србофобију и антијугословенске тежње у Хрватској током тзв. „Маспока” с почетка седамдесетих година прошлог века, Десанка преузима штуре податке писаних извора из прве трећине 10. века: од Бугара потучени српски жупан Захарија са својом војском „налази уточиште код хрватског краља Томислава", Хрвати и Срби заједно одолевају бугарском упаду и потом јача покрет за словенско богослужење, а тада је - како стоји у уводном запису ауторке - Хрватска „била моћна на копну и на мору”. Десанка учитава „Глас претков” који се обраћа бугарском цару речима да они „на које би да завојштиш, / твоја прадавна су, Царе, својта”, док тај исти глас опомиње и хрватског владара: „А около са сваке стране / не један предак / већ њих стотину / мрморе кроз ноћну тмину / или негде Краљу у души: / Дај Рашанима уточишта!” Перун је, очито, као заборављени заједнички ауторитет, потегнут у име идеје о међусобној упућености суседних, истокорених народа, упркос историјским препрекама. Велика српска песникиња је своје изрекла, као и историја, и пре и касније.

У запажене песме Стевана Раичковића убрајамо сонет „На Невском проспекту”. На главној улици Петрове престонице лирски субјект се обрео у несвагдашњем, мистички противречном доживљају (,Ја никад са душом овако блажом / Не стајах под небом горд, а мали"). Песник је саживљен с руским градом и пределом, исказује „унутрашње сведочанство бића” о својој примарној припадности: „Гле: златно кубе сред ноћне воде. / (То моје срце блешти у мраку.) / Ја као да видим: по житу и маку / Словенског себе који оде". Ипак, Раичковић још потпуније исказује словенску самосвест у своме необичном преводилачком подухвату, Словенске риме (1976). Уводна белешка његове преводне књиге, у којој окупља лирске одабранике разних словенских језика, поприма најинтимнији - више заветни неголи програмски карактер. Уместо да пружи кратка обавештења о концепту приређивача и преводиоца, Раичковић ову белешку претвара у танану исповест. Рукопис Словенских рима песник именује као својеврсно скровито место у којем је читаву деценију боравио: „Овим записом, као неким кључићем неуобичајена облика, отварам једну кутију по којој сам [...] пребирао по злату и сребру словенских речи” (1988: 201). Раичковић је, дуго и циљано, пребирао по лирици других словенских језика да их обједини својом лирском руком. У поенти записа развиђа линију што

„силази за читавих једанаест векова надоле: у једном истом оваквом дану, Константин Солуњанин, нешто касније названим Ћирило, исписао је првим словенским словима, глагољицом, коју је сам и измислио - и прву реченицу на једном од словенских говора. И та реченица (као и цела ова књига) била је превод из Јеванђелистара: Искони бе слово. У почетку беше реч” (202). 
Раичковић, значи, не почиње од Перуна него од прве писане реченице на језику испрва разумљивом свим Словенима. Ако се Растко поистоветио са Старим Словенима, Црњански са прецима граничарима, Раичковић то чини с ониме што је праодавно исписао прву реченицу словенским језиком на словенском писму. Лирска позиција, уосталом, и почива на почетним, основним ситуацијама, нарочито ако знамо да прва општесловенска реченица и упућује на сазнање да је Реч на почетку. И да та света реченица, Искони бе Слово, хтели не хтели, повезује све оне што су историјским трајањем постали безмерно удаљени или бесповратно отуђени.

Будући да је српска авангарда легитимисала садржаје најдубље културне прошлости и колективних почетака сачуване у свести модерног појединца, освешћени знакови прошлости постају нова упоришта, битни тематски пунктови. Признањем трансперсоналних садржаја свести издвајају се архетипски и културни симболи. Они се кристализују у поставангардној српској поезији с неизбежним словенским почетним знаком, али и с другим суседним културним траговима. Као настављачи међуратног програма југословенске и балканске културне еманципације, водећи послератни српски песници културе постају активатори разнородних елемената наслеђа којим је наслојен њихов културни простор. С почетне тачке авангардног словенског месијанизма, допрло се до развијене свести о још приснијој припадности матичном културном ареалу балканског подручја, као неизбежном тематско-симболичком поетском ресурсу.

\section{Извори}

Винавер С. Громобран свемира. Београд: Издање свесловенске књижарнице М. Ј. Стефановића и друга, 1921.

Винавер С. Земље које су изгубиле равнотежу. Дела Станислава Винавера. Књ. 14. Прир. Гојко Тешић. Београд: Службени гласник - Завод за уџбенике, 2015.

Драинац Р. Бунтовник и апостол. Дела. Други том. Београд: Завод за уџбенике и др., 1999.

Драинац Р. Силазак с Олимпа. Дела. Четврти том. Београд: Завод за уџбенике и др., 1999.

Мицић Љ. „Дело зенитизма.” Зенит, бр. 8, октобар 1921.

Мицић љ. „Зенит манифест 1922.” Зенит, бр. 11, фебруар 1922.

Мицић љ. „Папига и монопол 'хрватска култура'.” Зенит, бр. 24, мај 1923.

Настасијевић М. Есеји. Белешке. Мисли. Београд: СКЗ - Горњи Милановац: Дечје новине, 1991.

Петровић Р. „Једна теорија о пореклу Словена.” Прогрес, бр. 128, 1920.

Петровић Р. Есеји и чланичи. Дела Растка Петровића. Књ. VI. Београд: Нолит, 1974.

Раичковић С. Препеви. Сабрана дела. Београд: Завод за уџбенике и наставна средства, БИГЗ, СКЗ, 1988.

Црњански М. Путописи. Изабрана дела. Београд: Нолит, 1983.

Црњански М. Есеји и чланцฺи I. Београд: Задужбина Милоша Црњанског - Лозана: Наш дом, 1999.

Црњански М. Есеји и чланци II. Београд: Задужбина Милоша Црњанског - Лозана: Наш дом, 1999. 


\title{
Литература
}

Велимировић Н. Сабрана дела владике Николаја. Књ. 2. Ваљево: Глас Цркве, 1996. Велмар-Јанковић В. Огледи о књижевности и националном духу. Играчи на жици. Београд: Задужбина Светог манастира Хиландара, 2006.

Вујић В. Од Шиенглера до Светог Саве. Прир. Владимир Димитријевић. Београд: Жагор, 2013.

Голубовић В. „Руски мислиоци и Европа.” Нова Европа 1920-1941. Београд: Институт за књижевност и уметност, 1910: 239-240.

Димитријевић В. Тржиште или храм. Становиште Владимира Вујића. Београд: Cateria mundi, 2016, стр. 196-212.

Зењковски В. Руски мислиочи и Европа. Критика европске културе код руских мислилача. Прев. Марија и Бранислав Марковић. Београд: Логос, 2012.

Иванов В. Предосећања и предсказања. Прев. Ениса Успенски. Београд: Zepter Book World, 2001.

Лалић И. В. О поезији. Дела. IV. Београд: Завод за уџбенике и наставна средства, 1997.

Масарик Т. Г. Нова Европа. Словенско становиште. Прев. Александар Илић. Београд: Завод за уџбенике, 2016.

Мишић 3. Реч и време II. Песничко искуство. Београд: Нолит, 1963.

Нојман Е. Историјско порекло свести. Прев. Глигорије Ерњаковић. Београд: Просвета, 1994.

Павловић М. Поезија и култура. Београд: Нолит, 1974.

Петковић Н. Словенске пчеле у Грачаници. Београд: Завод за уџбенике, 2007.

Петковић Н. На извору живе воде. Београд: Завод за уџбенике, 2010.

Скерлић Ј. Историја нове српске књижевности. Београд: Завод за уџбенике, 2006. Суботић М. Тумачи руске идеје. Београд: Завод за уџбенике и наставна средства, 2001.

Трубецки Н. Европа и човечанство. Превод и поговор Вања Станишић. Београд: Логос, 2004.

Хамовић Д. Пут ка усправној земљи. Модерна српска поезија и њена културна самосвест. Београд: Институт за књижевност и уметност, 2016: 89-108.

\author{
Драган Л. Хамович
}

СЛАВЯНСКОЕ САМОСОЗНАНИЕ СОВРЕМЕННОЙ СЕРБСКОЙ ПОЭЗИИ

$$
\text { Резюме }
$$

Славянское самосознание в сербской поэзии широко распространяется после Первой мировой войны и после объединения югославских народов. Сербские авангардисты выдвигают требование эмансипации и уклонения от западных моделей и создания новой оригинальной (юго)славянской культуры. В основе таких послевоенных стремлений лежат идеи о славянском мессианизме, взращенные в недрах русской критической мысли о Европе, а также новой идеи Шпенглера о закате западной культуры, в то время как актуальный импульс им давала евразийская теория Николая Трубецкого. Трубецкой отрицает существование единой славянской культуры, полагая, что славянские народы развили особенные психические типы, и в русском случае он выступает за евразийскую культуру, а в югославском случае указывает на балканскую культуру. 
Станислав Винавер в программной книге «Громоотвод Вселенной» находит глубинные аналогии между революционным переворотом в обществе и искусстве и русской народной стихией, которую воплощает музыка Скрябина. Растко Петрович вводит фигуры старославянских предков, экстатических и витальных, а также бурлескных персонажей славянского пантеона. Милош Црнянский в лирике, а потом и в романе Переселение формирует исторический архетип славянского воина-наемника без отечества, который проливает кровь в Европе ради чужой выгоды. Антизападная позиция и идея югославского, а потом балканского мессианизма оставляют заметный след в «зенитистской» авангардной программе Любомира Мицича и в манифестах и поэзии Раде Драинаца, в идее новой и животворной всечеловеческой культуры.

Поскольку авангард узаконил содержание глубочайшего прошлого и коллективных начал, сохранившееся в сознании современного индивидуума, пробужденные знаки прошлого становятся тематически-символическими опорами. В современном открытии трансперсональных содержаний сознания выделяют архетипические символы, значение которых возрастает в поставангардной сербской поэзии. Васко Попа воплощает живое славянское начало в символах волка и дерева липы, которые пересекаются с другими, историческими фигурами, и эти славянские и сербские символы получают центральное место в его внимательно конструированном поэтическом универсуме. Миодраг Павлович фокусируется на переходной драме между славянским устной и письменной культурой, между язычеством и христианством, чтобы позднее переключить внимание на балканское культурное наследие, в котором, кроме славянского, переплетаются и другие слои. По этому пути пойдет и Любомир Симович, который содержание старой сербской мифологии и христианского предания встраивает непосредственно в жизненные ситуации родных просторов западной Сербии.

Десанка Максимович в послевоенный период обращается к образам свергнутых славянских богов, с которыми она может более непосредственно вступать в контакт, поскольку они, в соответствии с реконструкцией Чайкановича древней сербской религии, обоготворенные предки. Другим способом славянское самосознание выражает лирик Стеван Раичкович, который обычно последовательно избегает исторических и культурных ассоциаций. В сонете «На Невском проспекте» лирический субъект свидетельствует глубокую принадлежность к славянскому происхождению, что он программно выразил, собирая поэтов, пишущих на славянских языках, в книге Славянские рифмы (1976), во введении к которой проводит параллель между моментом своего писания с давним моментом, когда Константин (Кирилл) писал свое первое предложение, понятное всем славянам.

Ключевые слова: сербская современная поэзия, славянский неомифологизм, югославский мессианизм, культурное самосознание, евразийство, балканизм, культурные символы. 